OPEN ACCESS

Edited by:

Cristina Nabais,

University of Coimbra, Portugal

Reviewed by:

Gerald Moser,

Justus Liebig University Giessen,

Germany

Ana-Maria Heres,

National Museum of Natural History,

Spanish National Research Council,

Spain

*Correspondence:

Hannes Seidel

hseidel@wzw.tum.de

Specialty section This article was submitted to Functional Plant Ecology,

a section of the journa

Frontiers in Plant Science

Received: 29 January 2016

Accepted: 27 June 2016

Published: 07 July 2016

Citation:

Seidel H and Menzel A (2016)

Above-Ground Dimensions and Acclimation Explain Variation in Drought Mortality of Scots Pine Seedlings from Various Provenances.

Front. Plant Sci. 7:1014

doi: 10.3389/fpls.2016.01014

\section{Above-Ground Dimensions and Acclimation Explain Variation in Drought Mortality of Scots Pine Seedlings from Various Provenances}

\author{
Hannes Seide/ ${ }^{1 *}$ and Annette Menzel ${ }^{1,2}$ \\ ${ }^{1}$ Professorship of Ecoclimatology, Department of Ecology and Ecosystem Management, TUM School of Life Sciences \\ Weihenstephan, Technische Universität München, Freising, Germany, ${ }^{2}$ Institute for Advanced Study, Technische Universität \\ München, Garching, Germany
}

Seedling establishment is a critical part of the life cycle, thus seedling survival might be even more important for forest persistence under recent and future climate change. Scots pine forests have been disproportionally more affected by climate change triggered forest-dieback. Nevertheless, some Scots pine provenances might prove resilient to future drought events because of the species' large distributional range, genetic diversity, and adaptation potential. However, there is a lack of knowledge on provenance-specific survival under severe drought events and on how acclimation alters survival rates in Scots pine seedlings. We therefore conducted two droughtinduced mortality experiments with potted Scots pine seedlings in a greenhouse. In the first experiment, 760 three-year-old seedlings from 12 different provenances of the south-western distribution range were subjected to the same treatment followed by the mortality experiment in 2014. In the second experiment, we addressed the question of whether acclimation to re-occurring drought stress events and to elevated temperature might decrease mortality rates. Thus, 139 four-year-old seedlings from France, Germany, and Poland were subjected to different temperature regimes (20122014) and drought treatments (2013-2014) before the mortality experiment in 2015. Provenances clearly differed in their hazard of drought-induced mortality, which was only partly related to the climate of their origin. Drought acclimation decreased the hazard of drought-induced mortality. Above-ground dry weight and height were the main determinants for the hazard of mortality, i.e., heavier and taller seedlings were more prone to mortality. Consequently, Scots pine seedlings exhibit a considerable provenance-specific acclimation potential against drought mortality and the selection of suitable provenances might thus facilitate seedling establishment and the persistence of Scots pine forest.

Keywords: die-back, climate change, experiment, drought, warming, acclimation, above-ground biomass, height 


\section{INTRODUCTION}

Numerous forest-diebacks have been observed in the last few decades triggered by recent climate change-related drought stress and heat spells (Allen et al., 2010) covering a wide range of climate zones from boreal to tropical regions. Risk of forest mortality may increase in the future as climate models project an increase of temperature and a decrease in precipitation. Thus, drought severity might be exacerbated by rising temperatures (Kirtman et al., 2013). Drought-induced tree mortality may have adverse effects on forest structure and ecological communities, ecosystem function and services as well as biosphere-atmosphere interactions (reviewed, e.g., in Anderegg et al., 2012).

Acclimation (adjustment to environmental changes) is a key process to resist re-occurring stress events (Kozlowski and Pallardy, 2002). Mechanisms involved in drought and warming acclimation comprise molecular, physiological, and structural adjustments. Molecular adjustment against drought typically enhances gene expression pathways for production of molecules, such as abscisic acid (ABA), proline, and soluble sugars, linked to the maintenance of turgor and cell integrity (Peñuelas et al., 2013). ABA additionally inhibits cell expansion and thus reduces growth (Lambers et al., 2008). Warming acclimation on the molecular level increases the synthesis of heat shock and antistress proteins (Peñuelas et al., 2013). Physiological drought acclimation comprises changes in resource allocation (Callaway et al., 1994; Peña-Rojas et al., 2005; Poorter et al., 2012), a decrease of photosynthetic activity (Rennenberg et al., 2006) and an increase of water use efficiency (Brodribb and Hill, 1998; Lloret et al., 2004a). Structural acclimation processes toward water stress are the reduction of total leaf area by leaf size reduction (Kubiske and Abrams, 1992; Martínez-Vilalta et al., 2009; GünthardtGoerg et al., 2013) or leaf shedding (Ogasa et al., 2013), the adjustment of the hydraulic system by altering xylem conduit dimensions (Eilmann et al., 2009; Bryukhanova and Fonti, 2012), leaf/sapwood area ratio and leaf-specific hydraulic conductivity (Martínez-Vilalta et al., 2009). Furthermore, reduction of aboveground biomass might be linked to increased drought resistance (Alía et al., 2001; Valladares et al., 2007).

The seedling stage is an ontogenetic phase that is very drought sensitive and prone to mortality (Hanson et al., 2001; Lloret et al., 2004b) likely due to lower carbohydrate reserves (Niinemets, 2010), smaller rooting volume and lower rooting depth than mature trees (Cavender-Bares and Bazzaz, 2000). In general, proposed mechanisms of drought-induced tree mortality are carbon starvation caused by depletion of carbohydrate pools (Galiano et al., 2011; Adams et al., 2013; Mitchell et al., 2013), hydraulic failure of xylem conduits impairing water transport (Anderegg and Anderegg, 2013; Mitchell et al., 2013; Salmon et al., 2015), and failure of phloem transport affecting carbon translocation (Sala et al., 2010; McDowell et al., 2011; Adams et al., 2013). Survival rates of seedlings under drought were found to depend on various traits. The survival of several Mediterranean tree species is negatively correlated with total plant dry mass, total leaf area and positively correlated to leaf area ratio and shoot-root ratio across species (Valladares and Sánchez-Gómez, 2006). Thus, trait characteristics indicating a higher transpiring surface are linked to higher mortality rates. Tree size in general increases the hazard of droughtinduced mortality (Bennett et al., 2015) which might be explained by an increased risk of hydraulic dysfunction with increasing tree height and greater leaf area $(\mathrm{McD}$ owell and Allen, 2015).

Successful and adequate seedling establishment is essential for sustainable forest cover and production. Decreasing seedling survival under climate change may hamper forest regeneration and thus result in alternative forest communities or even nonforest ecosystems (Anderson-Teixeira et al., 2013). Bussotti et al. (2015) proposed three mechanisms of forest adaption to future environmental conditions: persistence by acclimation and phenotypic plasticity, evolution or local adaptation, and migration or substitution of tree species. If natural migration cannot keep pace with the rate of climate change, assisted migration of more adapted alternative tree species, but also suitable provenances within the same species, might support timely adaptation. Several studies have demonstrated provenance differences in sensitivity and response to reduced water availability, indicated, e.g., by differences in shoot length, diameter increment, and stomatal conductance of Fagus sylvatica (Rose et al., 2009; Thiel et al., 2014; Knutzen et al., 2015), in height and dry weight of Picea abies (Modrzyński and Eriksson, 2002), and in stomatal conductance, transpiration rates, leaf hydraulic conductance, osmotic potential, loss of hydraulic conductivity, and water-use efficiency of Pinus halepensis (Tognetti et al., 1997; Klein et al., 2013). However, studies on provenancespecific drought mortality are rare. Mortality rates were evaluated for central and marginal provenances of F. sylvatica (Thiel et al., 2012), provenances of Quercus pubescens (Wellstein and Cianfaglione, 2014), Pinus ponderosa provenances from origins differing in summer drought (Cregg, 1994) and central provenances of Pinus sylvestris (Cregg and Zhang, 2001), but only $P$. ponderosa provenances differed in drought survival, although not significantly.

More than one-third of the forest diebacks reported by Allen et al. (2010) are linked to Scots pine (P. sylvestris L.) forests although this species is considered to be drought resistant (Ellenberg, 1988). Scots pine has an extensive latitudinal (Spain to Scandinavia) and longitudinal (Spain to the far east of Russia) distribution range covering various climate zones from Mediterranean to boreal habitats (Boratynski, 1991). The huge distribution of this species favors local adaptation of provenances to contrasting environmental conditions (Boratynski, 1991; Reich and Oleksyn, 2008). The southernmost rear age of the distribution range in Spain and Italy is composed of post-glacial relict populations (Boratynski, 1991) which might be of special importance for provenance-based assisted migration due to high levels of genetic differentiation (Hampe and Petit, 2005) or even adaptations to heat and drought (Alía et al., 2001). Scots pine is an isohydric species which aims at minimizing water loss by tight stomatal control (Irvine et al., 1998) as well as by adjustment of leaf/sapwood area ratio, leaf-specific hydraulic conductivity, total leaf area, and conduit size (Sterck et al., 2008; MartínezVilalta et al., 2009). This drought avoiding strategy by closing stomata is implemented at the cost of reduced photosynthetic 
carbon gain (Mitchell et al., 2013), thus the risk of droughtinduced mortality might be especially observed under moderate but long lasting droughts. Regarding local adaptations, Scots pine provenances show differing drought responses in seedling establishment (Richter et al., 2012), in shoot diameter and height increment (Taeger et al., 2013a, 2015), and drought resistance (Taeger et al., 2013b).

However, there is a lack of knowledge how drought acclimation and provenance effects (adaptation) may impact mortality rates of $P$. sylvestris which would allow optimizing the provenance choice for assisted migration. In order to address this issue, we conducted two drought mortality experiments with potted Scots pine seedlings. The first mortality experiment in 2014 was based on 12 different Scots pine provenances from its south-western distribution in Europe. The second mortality experiment was conducted in 2015 and investigated seedlings of three provenances that had been acclimated to different seasonal drought events and temperature regimes before. Drought acclimation included a spring and a summer drought in 2013 and a spring drought in 2014. All drought acclimation treatments were applied within two temperature regimes, namely ambient air temperature and passively elevated temperature in a greenhouse. We hypothesized that (1) the hazard of mortality induced by a severe drought treatment differs across provenances, (2) acclimation by previous drought events and elevated temperature decreases the hazard of droughtinduced mortality, and (3) the hazard rate depends on the climate at the provenances' origin.

\section{MATERIALS AND METHODS}

\section{Plant Material}

Scots pine seedlings originated from 12 provenances distributed along their south-western distribution. Climatic conditions at the origin of the seeds range between $\sim 3$ and $11^{\circ} \mathrm{C}$ annual mean temperature and $\sim 600$ and $1100 \mathrm{~mm}$ of annual precipitation comprising western Mediterranean (Spain, France, and Italy) and continental (Switzerland, Germany, Poland, Hungary, and Bulgaria) sites (Table 1). Plants were grown from seeds in a nursery in south-eastern Germany in 2011. All seeds were collected from autochthonous populations, except for Alpenkiefer from Germany and Plantage Pornoapati from Hungary which were obtained from seed orchards. In 2012, seedlings were brought to the Gewächshauslaborzentrum (GHL) near Freising, Germany, where they were potted into 31 pots containing peat substrate. Seedling treatments/acclimation and provenances studied differed between the first mortality experiment conducted in 2014 and the second one conducted in 2015 as explained in the next chapters.

\section{Mortality Experiment 2014}

Seedlings used in the first mortality experiment in 2014 comprised all 12 provenances listed in Table 1 . In contrast to the second mortality experiment (see Mortality Experiment 2015 and Acclimation Treatments), they had not experienced any prior acclimation treatment and had been exclusively grown in the greenhouse. In total, 760 individuals were examined, but numbers of individuals per provenance varied between 31 and 187 individuals per provenance (Table 2). They were randomly arranged on three tables next to each other in a greenhouse (Figure 1A). All pots got well watered manually until the lethal drought treatment started by withholding irrigation (March 26 to July 1, 2014).

\section{Mortality Experiment 2015 and Acclimation Treatments}

In total, 139 seedlings were studied in the second mortality experiment in 2015. They comprised three provenances (Alpenkiefer, D; Mont Ventoux, F; Suprasl, PL) with 43, 44, and 52 individuals, respectively (Table 2). These seedlings were remnants of an extensive seasonal drought and warming experiment on more than 1000 individuals from 10 European Scots pine provenances. Out of these, three provenances were selected in order to provide sufficient sample sizes and to cover contrasting climatic conditions/seasonal precipitation

TABLE 1 | Origin of seeds used in the mortality experiments.

\begin{tabular}{|c|c|c|c|c|c|c|c|}
\hline Provenance abbreviation & Provenance & Country & Latitude & Longitude & Altitude (m) & $T\left({ }^{\circ} \mathrm{C}\right)$ & PPT (mm) \\
\hline PL9 & Suprasl, PL & Poland & $53^{\circ} 15^{\prime} \mathrm{N}$ & $23^{\circ} 23^{\prime} \mathrm{E}$ & 181 & 6.6 & 584 \\
\hline D8 & Mittel-/Ostdt. Tiefland, D & Germany & $53^{\circ} 04^{\prime} \mathrm{N}$ & $13^{\circ} 29^{\prime} \mathrm{E}$ & 75 & 8.5 & 574 \\
\hline D6 & Hauptsmoorwald, D & Germany & $49^{\circ} 51^{\prime} \mathrm{N}$ & $10^{\circ} 58^{\prime} \mathrm{E}$ & 250 & 8.8 & 646 \\
\hline D7 & Alpenkiefer, D & Germany & $47^{\circ} 30^{\prime} \mathrm{N}$ & $11^{\circ} 20^{\prime} \mathrm{E}$ & 1150 & 3.2 & 1106 \\
\hline HU14 & Plantage Pornoapati, HU & Hungary & $47^{\circ} 20^{\prime} \mathrm{N}$ & $16^{\circ} 28^{\prime} \mathrm{E}$ & 300 & 10.0 & 598 \\
\hline $\mathrm{CH} 5$ & Wallis, $\mathrm{CH}$ & Switzerland & $46^{\circ} 18^{\prime} \mathrm{N}$ & $07^{\circ} 39^{\prime} \mathrm{E}$ & 900 & 7.2 & 1025 \\
\hline 14 & Emilia Romagna, I & Italy & $44^{\circ} 30^{\prime} \mathrm{N}$ & $10^{\circ} 27^{\prime} \mathrm{E}$ & 460 & 10.8 & 888 \\
\hline F12 & Mont Ventoux, F & France & $44^{\circ} 10^{\prime} \mathrm{N}$ & $05^{\circ} 16^{\prime} \mathrm{E}$ & 1600 & 3.9 & 1166 \\
\hline F3 & Prealpes du Sud, F & France & $43^{\circ} 45^{\prime} \mathrm{N}$ & $06^{\circ} 40^{\prime} \mathrm{E}$ & 1185 & 7.6 & 955 \\
\hline ES1 & Alto Ebro, ES & Spain & $42^{\circ} 59^{\prime} \mathrm{N}$ & $03^{\circ} 17^{\prime} \mathrm{W}$ & 860 & 10.1 & 940 \\
\hline$B G 10$ & Garmen, BG & Bulgaria & $41^{\circ} 43^{\prime} \mathrm{N}$ & $23^{\circ} 54^{\prime} \mathrm{E}$ & 1300 & 6.6 & 649 \\
\hline ES2 & Montes Universales, ES & Spain & $40^{\circ} 28^{\prime} \mathrm{N}$ & $01^{\circ} 53^{\prime} \mathrm{W}$ & 1670 & 7.8 & 644 \\
\hline
\end{tabular}

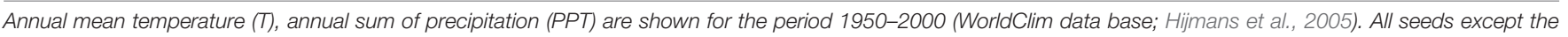
provenances HU14 and D7 (seed orchards) are from autochthonous stands. Provenances are arranged in decreasing order of latitude. 
TABLE 2 | Number of replicates, percentage of mortality after the lethal drought period, above-ground dry weight and height for different provenances, drought treatments and buildings (temperature regimes) in the mortality experiments in 2014 and 2015.

\begin{tabular}{|c|c|c|c|c|}
\hline Provenance & $N$ & Percent mortality & Weight $\pm S D(g)$ & Height $\pm S D(\mathrm{~mm})$ \\
\hline \multicolumn{5}{|c|}{ Mortality experiment 2014 (March 26 to July 1) } \\
\hline Suprasl, PL & 50 & 96.00 & $27.61 \pm 6.74^{a b}$ & / \\
\hline Mittel-/Ostdt. Tiefland, D & 41 & 92.68 & $30.46 \pm 7.10^{\mathrm{ac}}$ & / \\
\hline Hauptsmoorwald, D & 31 & 96.77 & $28.00 \pm 5.67^{a b d}$ & / \\
\hline Alpenkiefer, D & 54 & 98.15 & $34.82 \pm 6.54^{c}$ & / \\
\hline Plantage Pornoapati, HU & 52 & 98.08 & $31.78 \pm 7.33^{\mathrm{bc}}$ & / \\
\hline Wallis, $\mathrm{CH}$ & 94 & 97.87 & $22.39 \pm 9.26^{e}$ & / \\
\hline Emilia Romagna, I & 42 & 80.95 & $30.59 \pm 7.35^{\mathrm{ac}}$ & / \\
\hline Mont Ventoux, F & 57 & 98.25 & $27.42 \pm 7.05^{a b}$ & / \\
\hline Prealpes du Sud, F & 47 & 85.11 & $26.57 \pm 8.48^{\text {aef }}$ & / \\
\hline Alto Ebro, ES & 56 & 96.43 & $25.67 \pm 6.99^{a e}$ & / \\
\hline Garmen, BG & 49 & 89.80 & $30.71 \pm 7.64^{\mathrm{bcf}}$ & / \\
\hline Montes Universales, ES & 187 & 94.12 & $23.33 \pm 8.77^{\text {de }}$ & / \\
\hline \multicolumn{5}{|c|}{ Mortality experiment 2015 (May 22 to August 31) } \\
\hline Suprasl, PL & 52 & 98.08 & $153.88 \pm 55.05^{a}$ & $1030.85 \pm 260.65^{a}$ \\
\hline Alpenkiefer, D & 43 & 100.00 & $182.23 \pm 47.98^{b}$ & $956.19 \pm 141.67^{a}$ \\
\hline Mont Ventoux, F & 44 & 100.00 & $133.93 \pm 38.61^{a}$ & $734.84 \pm 158.60^{b}$ \\
\hline \multicolumn{5}{|c|}{ Drought treatment 2013 (spring-summer) } \\
\hline Control-control & 36 & 100.00 & $168.39 \pm 50.52^{a}$ & $1001.28 \pm 246.49^{a}$ \\
\hline Control-drought & 34 & 100.00 & $153.89 \pm 47.26^{a}$ & $923.21 \pm 215.58^{a}$ \\
\hline Drought-control & 37 & 100.00 & $156.64 \pm 51.18^{a}$ & $862.81 \pm 222.80^{a}$ \\
\hline Drought-drought & 32 & 96.88 & $145.11 \pm 56.61^{a}$ & $865.44 \pm 233.59^{a}$ \\
\hline \multicolumn{5}{|c|}{ Drought treatment 2014 (spring) } \\
\hline Control & 58 & 100 & $190.65 \pm 46.51^{a}$ & $991.07 \pm 244.67^{a}$ \\
\hline Drought & 81 & 98.77 & $131.49 \pm 39.39^{b}$ & $858.90 \pm 211.71^{b}$ \\
\hline \multicolumn{5}{|l|}{ Building 2012-2014 } \\
\hline Vegetation Hall & 65 & 100 & $173.10 \pm 44.23^{a}$ & $1014.23 \pm 191.79^{a}$ \\
\hline Greenhouse & 74 & 98.65 & $141.87 \pm 53.23^{b}$ & $826.05 \pm 234.34^{b}$ \\
\hline
\end{tabular}

Height was not measured in 2014. In the mortality experiment 2015, the seedlings were acclimated in different drought and temperature regimes during 2013 and 2014.

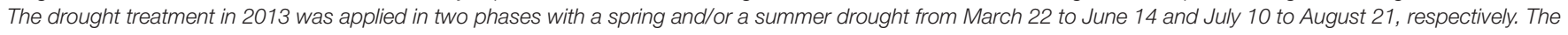

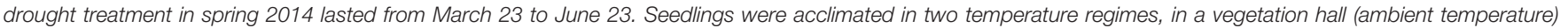

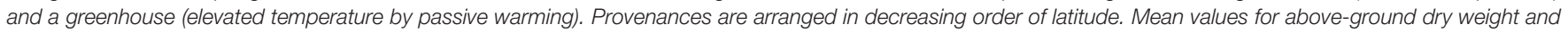

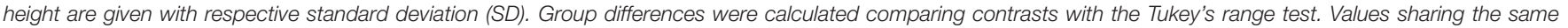
letter are not significantly different.

patterns (Table 1, Supplementary Figure S1). Prior to this second mortality experiment seedlings were subjected to two different temperature acclimation treatments, and within each they were exposed to drought acclimation treatments in 2013 and 2014 in order to study the influence of carry-over effects on mortality (see description of acclimation treatments below). In March 2014, seedlings were replanted from 31 pots into 201 pots containing peat substrate of identical composition as before. All 139 plants were put together in the greenhouse in December 2014 (Figure 1B), were randomly distributed on three tables and got well watered till the start of the mortality experiment in May 2015. During the lethal mortality experiment, irrigation was totally intermitted from May 22 to August 31, 2015.

\section{Temperature Acclimation}

Seedlings were grown under two temperature regimes from mid of 2012 till end of 2014 (Supplementary Figure S2). During this period 65 of the 139 seedlings were placed in a vegetation hall (glass-roofed building with open sidewalls), and 74 seedlings were placed in the greenhouse. Temperatures in the vegetation hall were similar to ambient conditions, but passive warming of the greenhouse increased temperatures. Within each building, air temperature and relative humidity $(\mathrm{RH})$ were recorded in 10-min intervals with a temperature/RH data logger (HOBO U23 Pro v2, Hobo ${ }^{\circledR}$, Onset Computer Corporation, Bourne, MA, USA). The vapor pressure deficit (VPD) was calculated using air temperature and $\mathrm{RH}$ as input variables after Allen et al. (1998) as a measure of atmospheric dryness. The mean temperature difference during 2013 and 2014 between the vegetation hall and the greenhouse was $3.0^{\circ} \mathrm{C}$ (Supplementary Figure S2B); however, the difference was more pronounced in frost periods (defined as periods with days having temperatures below $0^{\circ} \mathrm{C}$ ), i.e., $5.7^{\circ} \mathrm{C}$ (January 1 to April 8,2013 ), $4.0^{\circ} \mathrm{C}$ (November 12, 2013 to April 17, 2014) and $5.8^{\circ} \mathrm{C}$ (December $8-11,2014)$ than in frost-free summer periods $\left(1.3^{\circ} \mathrm{C}\right.$ in 2013 and $2.3^{\circ} \mathrm{C}$ in 2014$)$. The daily means of VPD were in general 


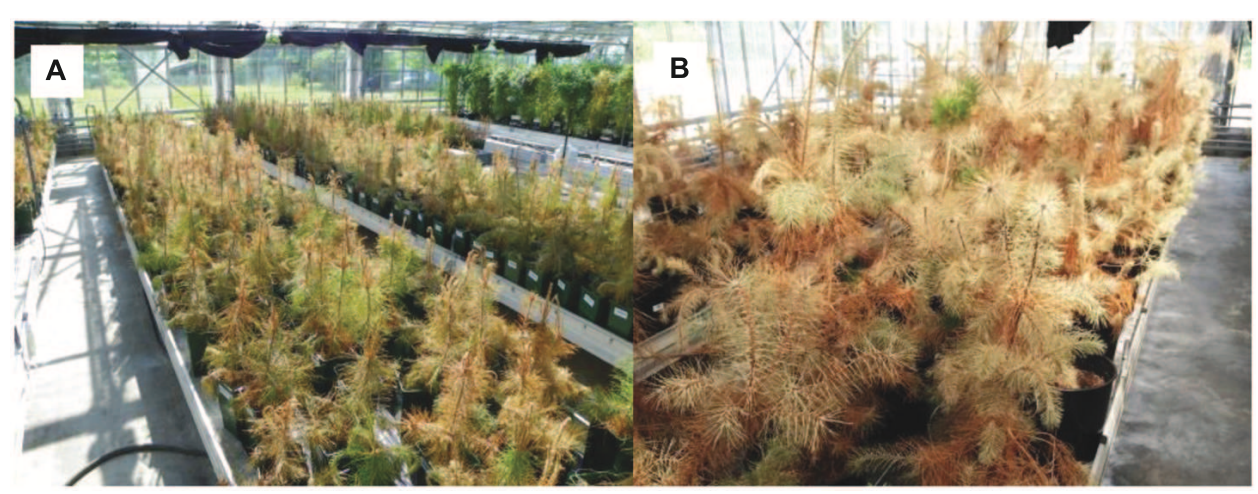

FIGURE 1 | Scots pine seedlings of different provenances in the mortality experiments. (A) After 83 days of total withholding of water in 2014 (mortality experiment from March 26 to July 1, 2014). (B) After 75 days of total withholding of water in 2015 (mortality experiment from May 22 to August 31,2015$).$

higher in the greenhouse than in the vegetation hall with some exceptions during the whole acclimation period (Supplementary Figure S2D). The overall mean VPD during 2013 and 2014 was $0.16 \mathrm{kPa}$ higher in the greenhouse than in the vegetation hall.

\section{Drought Acclimation in 2013 and 2014}

The drought acclimation comprised three drought periods in total (two in 2013, one in 2014), identical within each temperature regime, and accompanied by respective well-watered control groups (Supplementary Figure S3). In 2013, the drought was applied in two separated periods with a spring and/or a summer drought from March 22 to June 14 and July 10 to August 21, respectively. In both periods, automated irrigation was stopped and thereafter, soil moisture was adjusted to oscillate around the permanent wilting point by adding small amounts of water when necessary. The permanent wilting point $(\mathrm{pF}$ 4.2) corresponded to $12 \mathrm{Vol} \%$ soil moisture derived from water retention curves following the pressure plate method by Richards (1941). Thus, drought treated seedlings had to survive near the limit (permanent wilting point) for around 5 weeks in spring and for around 4 weeks in summer 2013 and got well-watered in between. The control and the three drought treatment groups (spring drought, summer drought, spring and summer drought 2013) comprised 32-37 individuals (Table 2).

These individuals of 2013 were split to a spring drought and well-watered control group in 2014, all within their respective temperature regime. This drought acclimation treatment lasted from March 23 to June 23 by totally withholding irrigation. Soil moisture fell below the permanent wilting point for around 5 weeks. Fifty-eight individuals belonged to the watered control group and 81 individuals were part of the drought acclimation group.

Soil moisture was monitored twice a week in the afore mentioned overarching experiment using a hand-held soil moisture sensor (UMP1, Umwelt-Geräte-Technik GmbH, Müncheberg, Germany) on 240 pots equally spread across provenances and treatments (Supplementary Figure S3).

\section{Mortality, Above-Ground Dry Weight and Height Assessment and Meteorological Conditions during the Mortality Experiments}

Mortality assessment was done with a knife carefully scratching the bark. The seedlings were classified as alive if the cambium tissue underneath the bark was green and classified as dead when this tissue was brownish. Evaluation of mortality was done on six dates in 2014 from April 28 to July 1 (day 33, 54, 62, 76, 82, and 97 after the lethal drought started) and almost once a week between June 2 and August 31 in 2015 (on day 12, 19, 26, 32, 40, 47, 54, $61,68,75,82,88$, and 102 after initiation of the lethal drought treatment). In 2015, the height of seedlings was measured at the beginning of the experiment from the substrate surface to the terminal tip using a folding rule. After each mortality experiment, above-ground biomass was harvested and oven dried at $60^{\circ} \mathrm{C}$ for $48 \mathrm{~h}$ to assess total above-ground dry mass.

Meteorological conditions were variable between the mortality experiments conducted in 2014 (March 26 to July 1) and in 2015 (May 22 to August 31). During the study periods mean temperature, mean $\mathrm{RH}$, and mean VPD were 16.6 and $24.5^{\circ} \mathrm{C}$; 62.5 and $54.7 \%$; and 0.9 and $1.6 \mathrm{kPa}$ in 2014 and 2015, respectively. Variables ranged from 2.9 to $39.1^{\circ} \mathrm{C}, 21.9$ to $93 \%$, and 0.1 to $5.3 \mathrm{kPa}$ in 2014 ; and from 11.2 to $41.6^{\circ} \mathrm{C}, 18.8$ to $88.5 \%$, and 0.2 to $6.3 \mathrm{kPa}$ in 2015, clearly indicating that the lethal drought stress in summer 2015 was higher than in spring 2014.

\section{Statistics}

\section{Above-Ground Dimensions (Seedling Height and Above-Ground Dry Weight)}

The effect of provenances and acclimation treatments on seedlings' above-ground dry weight and height was evaluated separately using linear models (stats, R Core Team, 2015) in $R$ 3.2.2. In the case of analyzing above-ground biomass in the mortality experiment in 2014, just provenance (12 different provenances) served as an explanatory variable. For analyzing above-ground biomass and height in the mortality experiment in 2015, explanatory variables were provenance (three different 
ones), drought acclimation treatment 2013 (only spring drought, only summer drought, spring and summer drought, and control), drought acclimation treatment 2014 (spring drought, control) and building (vegetation hall, greenhouse). Provenance, drought acclimation treatment and temperature acclimation treatment (building) were incorporated in the models as factorial dummy variables; more precisely, as the presence or absence of drought and the affiliation to vegetation hall (ambient temperatures) or greenhouse (elevated temperatures).

\section{Survival Analysis}

Survival analysis was conducted using a Cox proportional hazards regression model (survival package in R; Therneau and Grambsch, 2000). This type of model calculates the hazard ratio (HR) that is the probability of a death event in the treatment group in relation to the probability in the reference group. The covariates provenance and above-ground dry weight as well as their two-way interaction were added to analyze mortality of Scots pine seedlings in the mortality experiment 2014.

Two different models were constructed to analyze mortality and the effect of covariates on the drought hazard in the 2015 experiment. The first model contained the covariates provenance, drought treatments in 2013, drought treatment in 2014, temperature regime and the two-way interactions of provenance with drought treatments in 2013, drought treatment in 2014 and temperature regime (so called factorial model). The second model to analyze the 2015 mortality experiment included, in addition to the covariates and twoway interactions of the first model, seedling height and aboveground dry weight (so called continuous model). Provenance, drought acclimation treatment and temperature acclimation treatment were incorporated in the models as factorial dummy variables as explained above. Since above-ground biomass and height varied significantly between levels of provenances and hardening treatments (Table 2, see Supplementary Tables S1 and S2 for the summary output of linear models), weight and height were centered on respective group means to avoid confounding effects of covariates with tree dimension effects.

All survival models were simplified by stepwise excluding covariates/interactions that did not improve the models explanatory power with the Anova function (car, Fox and Weisberg, 2011). The proportional hazard assumption was checked by examining diagnostic plots and with the cox.zph function (survival; Therneau and Grambsch, 2000).

Pairwise comparisons in the linear and Cox proportional hazard models were done using the glht function (multcomp, Hothorn et al., 2008) comparing contrasts with the Tukey's range test and the false discovery rate method was applied to correct $p$-values for multiple comparisons.

\section{RESULTS}

\section{Seedling Dimensions}

Seedling dimensions (above-ground dry weight and height) varied across provenances and acclimation treatments (Table 2;
TABLE 3 | Analysis-of-variance table evaluating the set of covariates included in final Cox proportional hazards regression models using partial-likelihood ratio test.

\begin{tabular}{lccr}
\hline Covariates & LR & df & $\boldsymbol{p}$ \\
\hline Mortality experiment 2014 & & & \\
Provenance & 74.856 & 11 & $<\mathbf{0 . 0 0 1}$ \\
Weight & 14.693 & 1 & $<\mathbf{0 . 0 0 1}$ \\
Mortality experiment 2015: factorial model & & \\
Drought treatment 2014 & 18.94 & 1 & $\mathbf{0 . 0 0 1}$ \\
Provenance & 3.22 & 2 & 0.200 \\
Building & 14.875 & 1 & $<\mathbf{0 . 0 0 1}$ \\
Provenance: building & 6.667 & 2 & $\mathbf{0 . 0 3 6}$ \\
Mortality experiment 2015: continuous model & & $\mathbf{0 . 0 0 5}$ \\
Height & 7.816 & 1 & $\mathbf{0 . 0 0 6}$ \\
Weight & 7.487 & 1 & $<\mathbf{0 . 0 0 1}$ \\
Drought treatment 2014 & 20.238 & 1 & 0.171 \\
Provenance & 3.535 & 2 & $\mathbf{0 . 0 0 1}$ \\
Building & 12.814 & 1 & $\mathbf{0 . 0 0 5}$ \\
Provenance: building & 10.488 & 2 &
\end{tabular}

Bold values indicate significance at a level of 0.05 .

see also Supplementary Tables S1 and S2 for detailed summary output of models). In the mortality experiment in 2014, the provenance with the largest mean above-ground dry biomass was the Alpenkiefer from Germany with $34.82 \mathrm{~g}$, being significantly heavier than the provenances Wallis, Hauptsmoorwald, Alto Ebro, Montes Universales, Mont Ventoux, Prealpes du Sud, and Suprasl. The provenance from Wallis had the lowest above-ground dry weight (22.39 g) and was significantly different from all other provenances except Alto Ebro, Montes Universales, and Prealpes du Sud. Significant differences across provenances with intermediate weight could be also found (Table 2). Both provenances from Spain (Alto Ebro, Montes Universales) had a lower above-ground biomass than Garmen, Plantage Pornoapati, Mittel-/Ostdt. Tiefland, and Emilia Romagna. Additionally, Montes Universales was lighter than Mont Ventoux and Suprasl, and Plantage Pornoapati was heavier than Prealpes du Sud.

Provenances used in the experiment in 2015 differed significantly in mean above-ground dry weight and mean height. The seedlings of Alpenkiefer (182.23 g) were heavier than the pines of Suprasl (153.88 g) and Mont Ventoux (133.93 g). The smallest mean height was scored for the provenance Mont Ventoux $(734.84 \mathrm{~mm})$ being significantly smaller than Alpenkiefer (956.19 mm) and Suprasl (1030.85 mm). Regarding the acclimation treatments (Table 2) no effect of the seasonal drought events in 2013 could be detected neither on mean above-ground biomass at the end of the experiment in August 2015 nor on seedling height. The drought in 2014 significantly affected mean above-ground dry biomass (190.65 g vs. $131.49 \mathrm{~g}$ ) and mean seedling height (991.07 vs. $858.9 \mathrm{~mm}$ ). Pines grown in the vegetation hall from 2012 to 2014 were significantly heavier (173.10 vs. $141.87 \mathrm{~g})$ and taller $(1014.23$ vs. $826.05 \mathrm{~mm})$ than those grown in the greenhouse. 


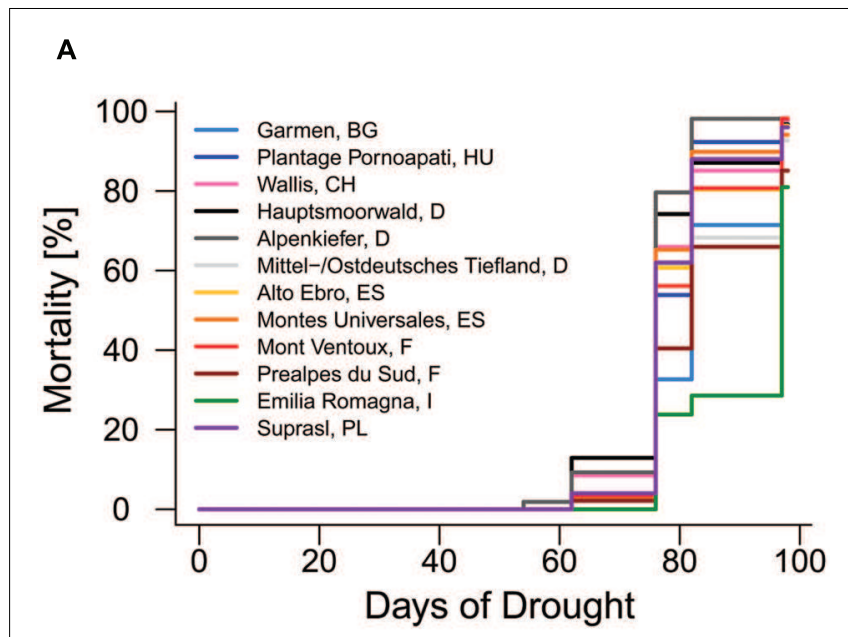

8

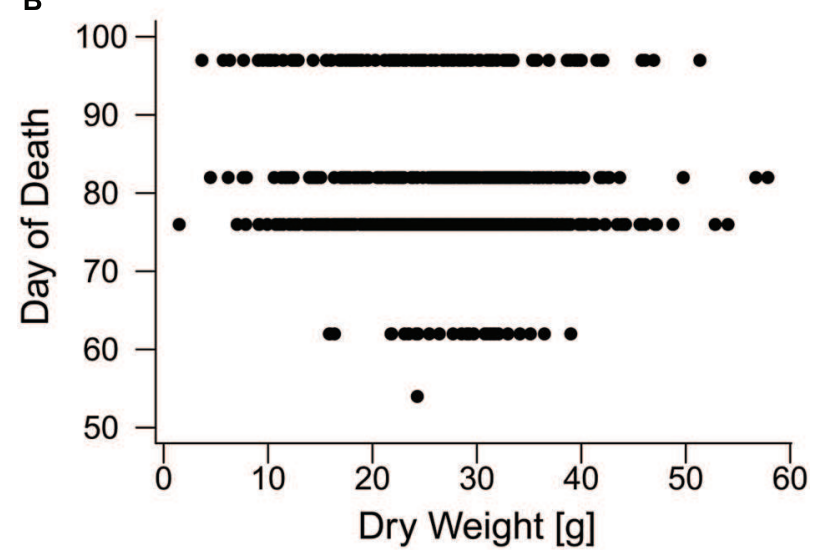

FIGURE 2 | Mortality in 2014. (A) Mortality rates of provenances during the mortality experiment. (B) Relationship between above-ground dry weight and the day when mortality was observed on one of the six observation days (day of death).

\section{Mortality 2014 \\ Mortality Rates and Influence of Above-Ground Dry Weight}

The first mortality events of Scots pine seedling were observed on the 54th day (second observation day) of the 97-day drought treatment in 2014 and most diebacks (415 out of 760) were detected on the 62nd day (third observation day) after the drought started (Figure 2A, Supplementary Figure S4A). Total mortality rates of the 12 provenances used in the experiment (Table 2) ranged between $81 \%$ (Emilia Romagna, I) and $98 \%$ (Mont Ventoux, F; Alpenkiefer, D; Plantage Pornoapati, HU; and Wallis, $\mathrm{CH}$ ). Variation in mortality rates of seedlings in 2014 could be explained by above-ground dry weight and provenances (Table 3, see Supplementary Table S3 for a detailed model summary). Above-ground dry weight significantly increased the HR by $1.7 \% / g(p<0.001$, Supplementary Table S4, Figure 2B), thus the hazard of the individual with the highest weight $(57.86 \mathrm{~g})$ had an almost $96 \%$ higher hazard of mortality than the individual with the lowest weight $(1.49 \mathrm{~g})$.

\section{Provenance Differences in Mortality Hazard Rates}

Provenances differed significantly in their hazard rate for mortality due to the severe drought event in the experimental setup (Figures 2A and 3, Supplementary Table S4). The provenance from Emilia Romagna (Italy) showed significantly lower hazard rates than all other provenances $(p<0.05)$ with the exception of the provenances Prealpes de Sud (France) and Garmen (Bulgaria), which were the second and third most drought resistant provenances in terms of mortality, respectively. Almost each provenance showed higher hazards than those three, except Mont Ventoux (France) and Alto Ebro (Spain) that did not indicate a higher mortality risk than the provenance Garmen (Bulgaria). Additionally, the provenance Mittel-/Ostdt. Tiefland (Germany) was not at higher risk than the provenances Prealpes de Sud (France) and Garmen (Bulgaria). The most vulnerable provenance in respect to the mortality hazard caused by severe drought was Alpenkiefer (Germany) that was at greater risk than Prealpes de Sud, Mont Ventoux (both France), Alto Ebro, Montes Universales (both Spain), Emilia Romagna (Italy), Garmen (Bulgaria), and Mittel-/Ostdt. Tiefland (Germany).

\section{Mortality 2015}

\section{Mortality Rates and Influence of Above-Ground Dimensions}

The drought mortality experiment in 2015 lasted 102 days. The first dead individual was observed on day 26 after drought initiation and most mortality events were observed on the 54th day of the drought treatment when 69 out of 139 individuals were recorded as dead (Supplementary Figure S4B). Total mortality rates (Table 2) were almost $100 \%$ in all three provenances (Alpenkiefer, D; Mont Ventoux, F; and Suprasl, PL) and for all acclimation groups (drought treatment 2013, drought treatment 2014 and building). Differences in the drought mortality hazard were explained by acclimation induced by the drought treatment in 2014 ( $p<0.001$, Table 3 ) as well as the interaction between provenance and building induced by growing seedlings in the two different buildings, thus temperature regimes, in the so called factorial model ( $p<0.05$, Table 3, see Supplementary Table S5 for a detailed model summary). Adding the covariates aboveground dry weight and height in the so-called continuous model increased model concordance from 0.74 to 0.81 (Supplementary Tables S5 and S6, respectively). Both covariates exhibited a significant influence on the $\operatorname{HR}(p<0.01$, Table 3 , see Supplementary Table S6 for a detailed model summary). The HR increased by $0.8 \% / g$ above-ground dry weight and by $0.2 \% / \mathrm{ml}$ height (Table 4, Figures 4C,D), thus resulting in a doubling of mortality hazard (increase by $199.5 \%$ ) between the lightest $(49.28 \mathrm{~g})$ and the heaviest individual (298.64 g) and in a more than doubling of mortality hazard (increase by $237.4 \%$ ) between the smallest $(305 \mathrm{~mm})$ and the tallest individual $(1492 \mathrm{~mm})$.

\section{Variation in Mortality Hazard Rates with Acclimation and Provenance}

Although drought mortality was almost $100 \%$ at the end of the lethal drought experiment in 2015 there were still differences in the mortality hazard among acclimation groups and provenances since the time span till maximum mortality was observed varied 


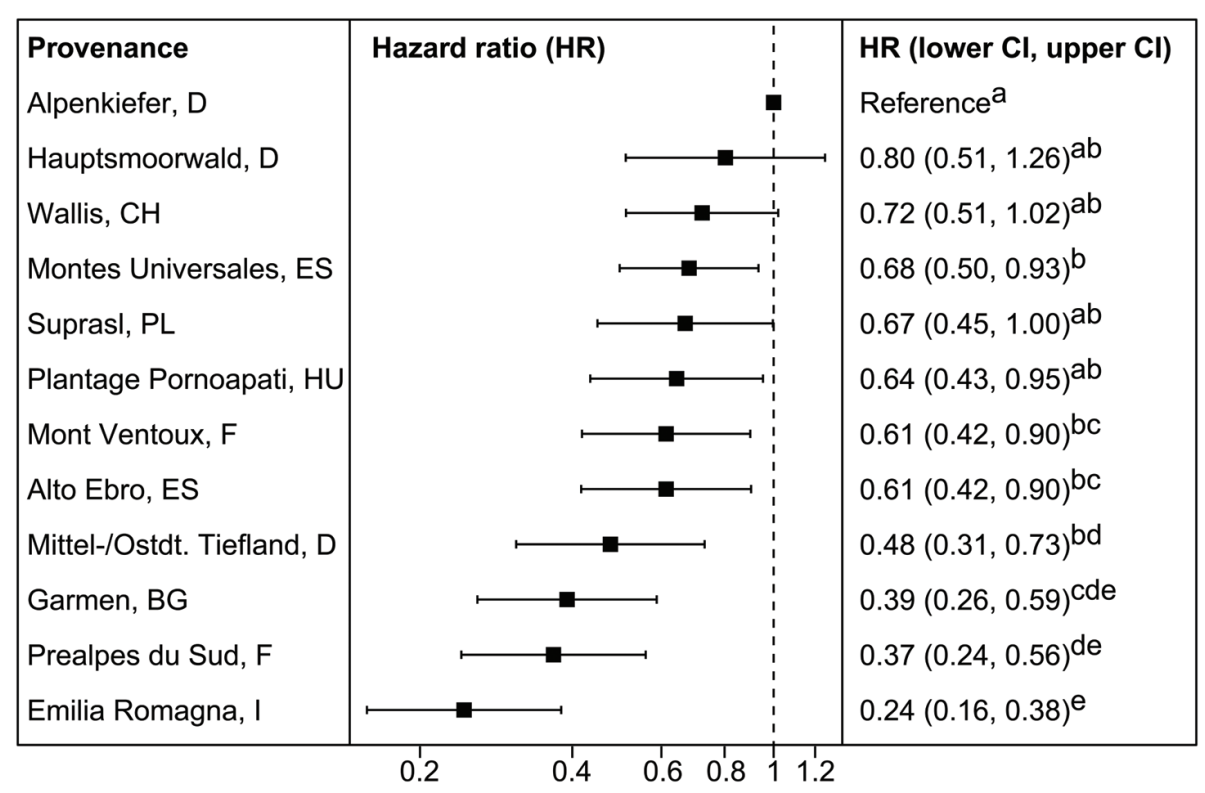

FIGURE 3 | Mean hazard ratios (HR) and confidence intervals (CI) of provenances investigated in the mortality experiment 2014 in relation to the reference provenance Alpenkiefer (D). Provenances are arranged in decreasing order of mean HR. Pairwise differences between provenances were calculated comparing contrasts with the Tukey's range test. HR sharing the same letter are not different at a significance level of 0.05.

between 75 and 102 days (Figure 4). The drought treatment in 2014 reduced the mortality hazard by $57.4 \%$ in the factorial model and by $59.6 \%$ in continuous model compared to the control (Table 4, Figure 4A). Variation in mortality hazard between provenances depended on the building (temperature regime) in which they were grown till December 2014. Whereas HR did not differ between provenances in the vegetation hall, they did in the greenhouse (Table 4, Figure 4B). The mortality hazard for Alpenkiefer (Germany) is 61 and $49.6 \%$ significantly higher $(p<0.05)$ than for Mont Ventoux (France) and Suprasl (Poland), as estimated with the factorial model. Mont Ventoux (France) and Suprasl (Poland) were not different in their mortality hazard. Adding the covariates above-ground dry mass and seedling height increased the difference in hazard between Alpenkiefer and Mont Ventoux to $67.6 \%$ and diminished the hazard between Alpenkiefer and Suprasl to $46.6 \%$, that was not significant anymore at the $5 \%$ level $(p=0.081)$. Growing in the vegetation hall till December 2014 increased the hazard of mortality in Mont Ventoux and Suprasl $(p<0.01)$, but not in Alpenkiefer compared to the hazard experienced in the greenhouse (Table 4, Figure 4B). Hazard in the vegetation hall was 188.1 and $277.7 \%$ higher for Mont Ventoux compared to the greenhouse as indicated by the factorial and continuous model, respectively. Suprasl showed a 177.6 and $138.9 \%$ higher mortality hazard in the vegetation hall compared to the greenhouse.

\section{DISCUSSION}

Drought mortality varied fundamentally across provenances which was to our knowledge not reported in literature before. Above-ground dimensions had a significant impact on the hazard of drought-induced mortality. Taller and heavier individuals died earlier than individuals which were smaller and had lower weights. Thus, there seems to be a trade-off between growth and drought survival (Alía et al., 2001; Bennett et al., 2015). Acclimating seedlings by drought in the year before the actual drought mortality experiment considerably lowered the mortality hazard. In the further paragraphs, we discuss the link between provenance and above-ground dimensions as well as the provenance and acclimation effects on the mortality hazards.

\section{Variation of Seedling Dimensions among Provenances and Acclimation Treatments}

Seedling dimensions (above-ground dry weight and seedling height) showed considerable variation among provenances and acclimation treatments. Differences in dry weight were consistent for provenances that were monitored in both mortality experiments in 2014 and 2015. Variation in biomass and height across provenances of $P$. sylvestris is well documented in literature. Oleksyn et al. (1992, 1998, 1999, 2000) showed that above-ground biomass and height of seedlings and adult trees had a hump-shaped relationship with the latitude of their origin, central provenances $\left(45-55^{\circ} \mathrm{N}\right)$ having higher aboveground biomass and height than the southern $\left(<45^{\circ} \mathrm{N}\right)$ and northern provenances $\left(>55^{\circ} \mathrm{N}\right)$. This pattern is similar for the latitudinal range $\left(40-53^{\circ} \mathrm{N}\right)$ in our study at least for aboveground dry weight, however, it has to be taken into account that the provenance Alpenkiefer is from a seed orchard. Oleksyn et al. (1999) attributed their findings to reduced day length and climate transfer distance in northern provenances and to 
TABLE 4 | Estimated main and interaction effects of the survival model including factorial covariates only (factorial model) and factorial with continuous covariates (continuous model) on hazard of mortality in the experiment 2015.

\begin{tabular}{|c|c|c|c|c|}
\hline & \multicolumn{2}{|c|}{ Factorial model } & \multicolumn{2}{|c|}{ Continuous model } \\
\hline & HR & $p$ & HR & $p$ \\
\hline \multicolumn{5}{|l|}{ Main effects } \\
\hline \multicolumn{5}{|c|}{ Drought treatment 2014} \\
\hline Control/drought & $1 / 0.426$ & $<0.001$ & 0.404 & $<0.001$ \\
\hline \multicolumn{5}{|l|}{ Dimensions } \\
\hline Height $(\Delta \mathrm{HR} / \mathrm{mm})$ & l & / & 1.002 & 0.005 \\
\hline Weight $(\Delta \mathrm{HR} / \mathrm{g})$ & / & / & 1.008 & 0.006 \\
\hline \multicolumn{5}{|c|}{ Interaction effects (pairwise comparisons) } \\
\hline \multicolumn{5}{|l|}{ Vegetation hall } \\
\hline D7/F12 & $1 / 1.084$ & 0.804 & $1 / 1.448$ & 0.409 \\
\hline D7/PL9 & $1 / 1.351$ & 0.732 & $1 / 1.507$ & 0.409 \\
\hline F12/PL9 & $1 / 1.246$ & 0.732 & $1 / 1.041$ & 0.901 \\
\hline \multicolumn{5}{|l|}{ Greenhouse } \\
\hline $\mathrm{D} 7 / \mathrm{F} 12$ & $1 / 0.390$ & 0.007 & $1 / 0.324$ & 0.001 \\
\hline D7/PL9 & $1 / 0.504$ & 0.033 & $1 / 0.534$ & 0.055 \\
\hline F12/PL9 & $1 / 1.293$ & 0.360 & $1 / 1.647$ & 0.081 \\
\hline \multicolumn{5}{|c|}{ Vegetation hall $($ VegH) vs. greenhouse $(\mathrm{GH})$} \\
\hline D7: GH/NegH & $1 / 1.036$ & 0.909 & $1 / 0.847$ & 0.606 \\
\hline F12: GH/NegH & $1 / 2.881$ & 0.001 & $1 / 3.777$ & 0.001 \\
\hline PL9: GH/NegH & $1 / 2.776$ & 0.001 & $1 / 2.389$ & 0.004 \\
\hline
\end{tabular}

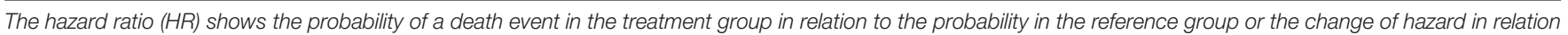

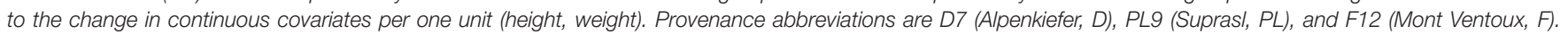
Group differences were calculated comparing contrasts with the Tukey's range test.

Bold values indicate significance at a level of 0.05 .

genetic adaptation to warm and arid environments in southern provenances.

Two of the acclimation treatments (drought treatment 2014, warming treatment building) had a significant impact on seedling dimensions in the mortality experiment 2015. Spring drought in 2014 reduced the seedlings' above-ground dimensions. Water stress is known to exert a negative influence on the rate of cell wall division and cell expansion (Hsiao and Acevedo, 1974). This is a direct effect of reduced turgor pressure (Hsiao and Acevedo, 1974) or an indirect effect of the suppression by growth regulators such as ABA (Peñuelas et al., 2013). Furthermore, Scots pine increases root-shoot ratio under dry conditions (Richter et al., 2012; Taeger et al., 2015), which might be caused by lower investment in above-ground structures (Alía et al., 2001; Taeger et al., 2013b, 2015).

Seedling above-ground dimensions were smaller when grown in the greenhouse under elevated temperatures from 2012 to 2015. Reich and Oleksyn (2008) reported that height growth of southern Scots pine provenances was negatively correlated with the absolute temperature difference between planting site and origin. Since all the provenances in our study belong to the geographical group which Reich and Oleksyn (2008) classified as southern provenances $\left(\leq 53^{\circ} \mathrm{N}\right)$ this may explain the finding of decreased seedling height at elevated temperature in the greenhouse and might also contribute to the lower above-ground biomass. Additionally, decreasing radial growth of $P$. sylvestris with increasing temperature (Martínez-Vilalta et al.,
2008; Michelot et al., 2012) could also contribute to lower aboveground biomass in the greenhouse compared to the vegetation hall.

The seasonal drought treatments (spring and/or summer drought) in 2013 did not affect dimensions measured in 2015. Most likely, effects induced by the drought treatment in 2013 were diluted since potting seedlings into much larger pots at the beginning of March 2014 caused an increase in overall mean above-ground dry weight by a factor of almost 6 (27.0 g in 2014 experiment, $156.4 \mathrm{~g}$ in 2015 experiment).

Nevertheless, the reduction of above-ground biomass might be an adaptation linked to drought tolerance, either across provenances or caused by acclimation (temperature, water availability).The reduction of above-ground biomass is linked to a decrease of foliage (Xiao and Ceulemans, 2004; Jagodziński and Kałucka, 2008) which is reducing evaporative water loss (DeLucia et al., 2000). Future work should also consider molecular and physiological acclimation pathways which might be associated with provenance.

\section{Mortality Hazard Rates}

Meteorological conditions during the 2015 mortality experiment were more severe than in the 2014 experiment, thus considerable first die-backs were observed after $\sim 60$ and $\sim 40$ days of completely withholding water, respectively.

It is difficult to disentangle acclimation effects (drought treatment 2014 and growing pines under different temperature 


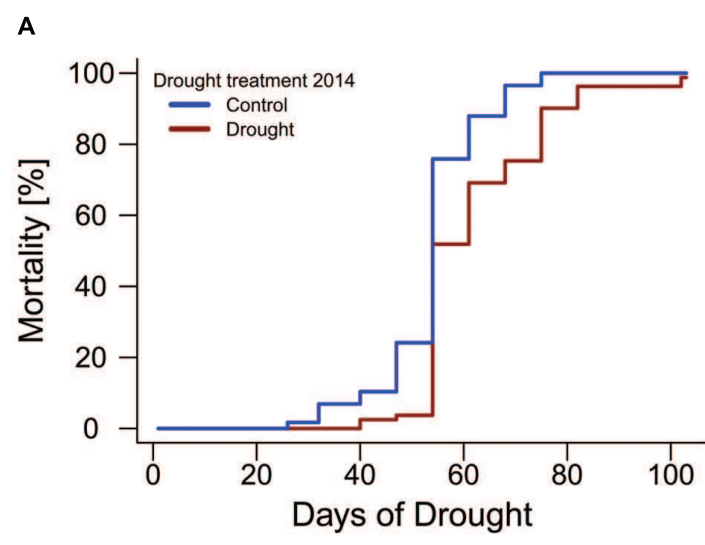

C

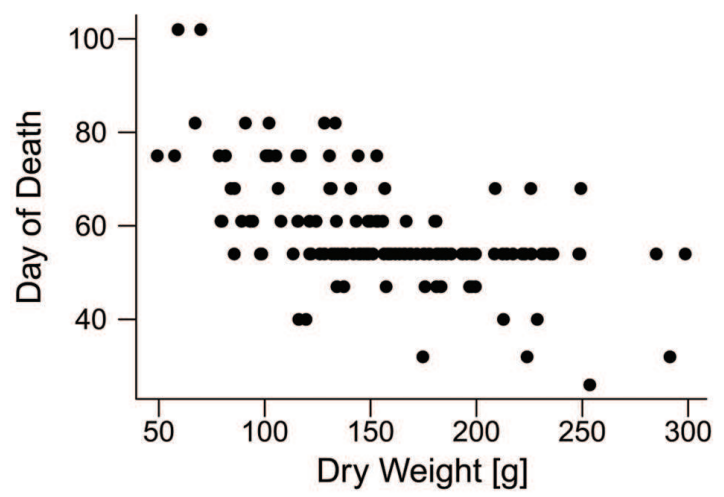

B

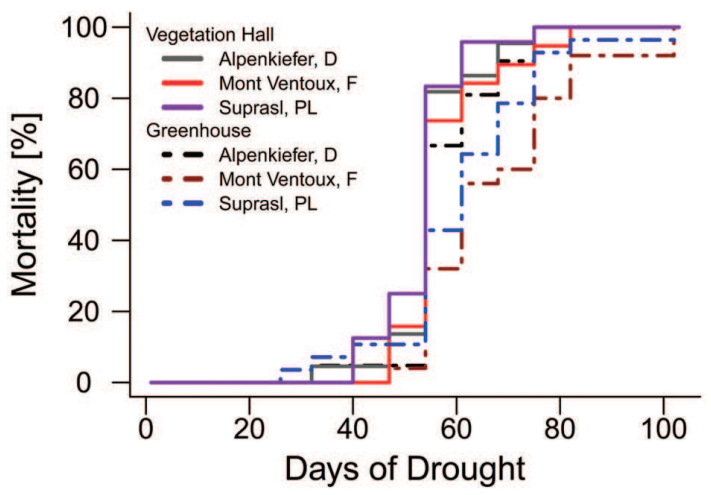

D

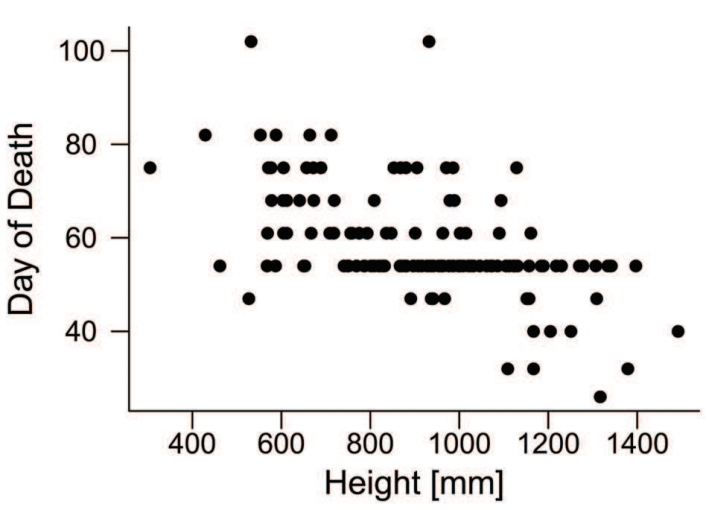

FIGURE 4 | Mortality rates of pines during the mortality experiment in 2015. (A) Influence of acclimation by the drought treatment in 2014 . (B) Effects of provenance and temperature acclimation on mortality rates. Relationship of (C) above-ground dry weight and (D) seedling height with the day when mortality was observed on the 13 observation days (day of death).

regimes) as well as provenance effects on mortality hazard rates from pure dimension effects (above-ground biomass and height) because both acclimation treatments and provenance influenced above-ground dimensions (Table 2, Supplementary Tables S1 and S2). We performed all survival modeling twice, with absolute dimensions (not reported in the paper) and with dimensions centered on respective means of acclimation treatments and provenances. In the latter case dimension effects were merely effects on the deviations from any provenance effect, and thus independent thereof. Since both attempts led to similar results, we conclude that (1) besides provenance and acclimation sheer above-ground dry weight (2014 experiment) and weight and height (2015 experiment) variations within provenances and treatments influenced mortality hazard (as presented in the Section "Result") and that (2) the provenance induced dimension differences were not the only provenance-treatment effects, as even by accounting for absolute differences in dimensions, there was still an additional provenance/acclimation effect, likely linked to physiological, wood anatomical differences, and/or adjustments.

\section{Provenance Effects on Mortality Hazard Rates}

Drought mortality was fundamentally different across provenances in both experiments, thus fully supporting our first hypothesis. This finding is novel since Cregg and Zhang (2001) could not find any variation in mortality rates of P. sylvestris seedlings from several Eastern European and Central Asian origins.

Opposite to our expectations, we could not identify any clear continuous relationship between provenance survival and the climate at their origin, such as mean annual temperature and mean annual precipitation sum (Table 1, data of correlation analysis not shown). However, the three provenances withstanding drought mortality the most (Emilia Romagna, Prealpes du Sud, Garmen) originate from locations with a pronounced precipitation minimum in summer, whereas the three provenances which were at the highest risk of drought mortality (Alpenkiefer, Hauptsmoorwald, Wallis) experience relatively high precipitation at their origin throughout the year (Supplementary Figure S1). F. sylvatica provenances originating from locations with summer drought had lower mortality rates under experimental induced extreme drought than provenances from wetter locations (Thiel et al., 2014). In contrast to their study, all the Scots pine provenances used in our study are from its south-western distribution range, which might blur an obvious drought survivalclimate relationship. Mortality rates in $P$. ponderosa could not been related to climatic variables either (Cregg, 1994). 
Rather to show a distinct pattern between mortality and climate, Ponderosa pine seems to have an optimum rootshoot ratio balancing water accessibility and photosynthetic capacity.

\section{Trade-Off between Growth and Drought Survival}

The hazard of mortality significantly varied with above-ground dimensions, a fact that was not explicitly mentioned in our hypotheses but was subsumed in the variable provenance. The mortality hazard increased with above ground dimensions suggesting a trade-off between growth and drought survival. In dry years, Alía et al. (2001) observed a lower branch dieoff on slow growing provenances than on faster growing ones. On a global scale, larger trees have higher mortality rates than smaller ones (Bennett et al., 2015). Since taller trees face greater challenges to lift water along height against gravity and conduit resistance, they are at higher risk of hydraulic dysfunction than smaller trees (McDowell and Allen, 2015). In neotropical savannas, larger trees lose $50 \%$ of hydraulic conductivity at higher values of water potential than smaller tress (Zhang et al., 2009). Taller trees counteract this hydraulic limitation by reducing stomatal conductance and leaf specific hydraulic conductance (Ryan et al., 2006) and since needle area is positively correlated with tree height and above-ground biomass (Xiao and Ceulemans, 2004; Jagodziński and Kałucka, 2008), this increases the hazard for hydraulic failure of larger trees (McDowell and Allen, 2015). Additionally, individuals with a larger transpiring needle area might exploit water resources faster than smaller individuals and thus die earlier under severe drought conditions.

\section{Acclimation Reduces the Hazard of Drought Induced Mortality}

Although we did not measure acclimation directly we suppose that exposure time to the treatments was sufficient since thermal acclimation can occur within hours to few days (Mäkelä et al., 2004; Lee et al., 2005). In addition, we could observe a change of above-ground dimensions caused by temperature and drought acclimation treatments in our study.

The drought acclimation treatment in 2014 significantly decreased mortality hazard rates as suggested in our second hypothesis. However, acclimation effects of 2013, two years prior to the mortality treatment, could not be identified any more, most likely due to the re-potting, significantly increasing seedlings' size. It might be worth to redo such a multiple acclimation mortality experiment without this confounding effect. Our finding of an acclimation effect in drought-induced mortality is in accordance to drought preconditioned Ponderosa pine seedlings which survived 2 weeks longer during drought than untreated seedlings and might be related to reduced gas exchange caused by stomatal control of water loss (Cregg, 1994).

It is known from literature that drought reduces needle area, decreases leaf/sapwood area ratio, and/or leads to smaller conduit sizes in Scots pine (Sterck et al., 2008; Martínez-Vilalta et al., 2009). Adjustments like these, might have favored higher survival rates under severe drought conditions in our study since they support avoidance of critical water potentials: Smaller leaf area results in lower transpiration rates reducing soil water exploitation (Verbeeck et al., 2007), decrease of leaf/sapwood area ratio results in total leaf area to be supported by a relatively larger area of water conducting tracheids (Mencuccini and Grace, 1995), and smaller conduit sizes increase resistance to cavitation (Sterck et al., 2012). Lower above-ground biomass and height of drought acclimated individuals in our study might also be linked to lower total needle area and thus preserves water transport and soil water resources by decreasing the risk of hydraulic failure and lower transpiration rates respectively. A drought induced decrease in leaf/sapwood area might be reflected by lower aboveground biomass in our study possible driven by lower needle biomass resulting in smaller total needle area.

The provenance-specific temperature effect on the hazard of mortality might be driven by changes in dimensions since variations in above-ground biomass follow the same pattern as hazard of mortality between provenances and buildings (data not shown) when only three provenances were considered in the mortality experiment 2015. As discussed above, elevated temperatures decrease height and diameter growth in Scots pine (Martínez-Vilalta et al., 2008; Reich and Oleksyn, 2008; Michelot et al., 2012). Additionally, high temperatures increase VPD, which was equally observed in our study. An increase of VPD alters biomass allocation reducing relative investment in leaf biomass (DeLucia et al., 2000), which in turn might decrease the hazard of mortality by a reduction of the transpiring surface.

However, it is also reported in the literature that exposure of seedlings to high temperatures can increase thermal tolerance caused by expression of heat shock proteins (Colombo and Timmer, 1992). Unfortunately little is known about their "lifetime" and thus it is unclear whether pines grown in the greenhouse and the vegetation hall from 2012 to 2014 still expressed different levels of heat shock proteins after growing exclusively in the greenhouse from December 11, 2014 till the start of the mortality experiment on May 22, 2015. The fact that in our study provenance effects were only apparent in the high temperature regime might suggest some association with heat shock proteins, however, this needs to be thoroughly tested in a follow-up study.

\section{CONCLUSION}

Above-ground dimensions were the main determinants of seedling mortality in Scots pine. Conversely, the pattern of provenances' specific hazards for drought mortality did not follow the pattern of above-ground biomass when 12 provenances were studied. Thus, also adaptations to local climate and genetic specific control of water relations (e.g., transpiration and stomatal conductance), which was observed in P. ponderosa and Pinus taeda (Seiler and Johnson, 1988; Monson and Grant, 1989), might play a dominating role in resistance to drought mortality. Our study revealed a clear acclimation potential of Scots Pine seedlings, since drought episodes and warmer temperatures increased their survival time 
under repeated stresses. This feature might facilitate Scots pine forest persistence under future climate change in the long run.

\section{AUTHOR CONTRIBUTIONS}

HS collected data, contributed to the experimental design, analyzed and interpreted the data, and wrote the paper. AM contributed to the conception of the work and experimental design, interpreted the data, and wrote the paper.

\section{FUNDING}

This work was financed by the European Research Council under the European Union Seventh Framework Programme (FP7/2007-2013/ERC grant agreement No. 282250).

\section{REFERENCES}

Adams, H. D., Germino, M. J., Breshears, D. D., Barron-Gafford, G. A., GuardiolaClaramonte, M., Zou, C. B., et al. (2013). Nonstructural leaf carbohydrate dynamics of Pinus edulis during drought-induced tree mortality reveal role for carbon metabolism in mortality mechanism. New Phytol. 197, 1142-1151. doi: 10.1111/nph.12102

Alía, R., Moro-Serrano, J., and Notivol, E. (2001). Genetic variability of Scots pine (Pinus sylvestris) provenances in Spain: growth traits and survival. Silva Fenn. 35, 27-38. doi: 10.14214/sf.601

Allen, C. D., Macalady, A. K., Chenchouni, H., Bachelet, D., McDowell, N., Vennetier, M., et al. (2010). A global overview of drought and heat-induced tree mortality reveals emerging climate change risks for forests. For. Ecol. Manage 259, 660-684. doi: 10.1016/j.foreco.2009.09.001

Allen, R. G., Pereira, L. S., Raes, D., and Smith, M. (1998). FAO Irrigation and Drainage Paper No. 56. Crop Evapotranspiration. Rome: FAO.

Anderegg, W. R. L., and Anderegg, L. D. L. (2013). Hydraulic and carbohydrate changes in experimental drought-induced mortality of saplings in two conifer species. Tree Physiol. 33, 252-260. doi: 10.1093/treephys/tpt016

Anderegg, W. R. L., Kane, J. M., and Anderegg, L. D. L. (2012). Consequences of widespread tree mortality triggered by drought and temperature stress. Nat. Clim. Chang. 3, 30-36. doi: 10.1038/nclimate1635

Anderson-Teixeira, K. J., Miller, A. D., Mohan, J. E., Hudiburg, T. W., Duval, B. D., and DeLucia, E. H. (2013). Altered dynamics of forest recovery under a changing climate. Glob. Chang. Biol. 19, 2001-2021. doi: 10.1111/gcb.12194

Bennett, A. C., McDowell, N. G., Allen, C. D., and Anderson-Teixeira, K. J. (2015). Larger trees suffer most during drought in forests worldwide. Nat. Plants 1:15139. doi: $10.1038 /$ nplants.2015.139

Boratynski, A. (1991). "Range of natural distribution," in Genetics of Scots Pine, eds M. Giertych and C. Mátyás (Amsterdam: Elsevier), 19-30.

Brodribb, T., and Hill, R. S. (1998). The photosynthetic drought physiology of a diverse group of southern hemisphere conifer species is correlated with minimum seasonal rainfall. Funct. Ecol. 12, 465-471. doi: 10.1046/j.13652435.1998.00213.x

Bryukhanova, M., and Fonti, P. (2012). Xylem plasticity allows rapid hydraulic adjustment to annual climatic variability. Trees 27, 485-496. doi: 10.1007/s00468-012-0802-8

Bussotti, F., Pollastrini, M., Holland, V., and Brüggemann, W. (2015). Functional traits and adaptive capacity of European forests to climate change. Environ. Exp. Bot. 111, 91-113. doi: 10.1016/j.envexpbot.2014.11.006

Callaway, R. M., DeLucia, E. H., and Schlesinger, W. H. (1994). Biomass allocation of montane and desert ponderosa pine: an analog for response to climate change. Ecology 75, 1474-1481. doi: 10.2307/1937470

Cavender-Bares, J., and Bazzaz, F. A. (2000). Changes in drought response strategies with ontogeny in Quercus rubra: implications for scaling from seedlings to mature trees. Oecologia 124, 8-18. doi: 10.1007/PL00008865

\section{ACKNOWLEDGMENTS}

We thank Ricardo Acevedo-Cabra for discussion, Charles Mellert for provision of WorldClim data, and especially Michael Matiu for discussion and comments on the manuscript, Gerda Benner, Philipp Falk, Elena Walter, and Stefanie Weindler for help with mortality assessment and Steffen Taeger, Andreas Ludwig (BaySF) and the ASP/Teisendorf for providing plant and seed material. We further thank the team of the GHL Dürnast for handling plant material.

\section{SUPPLEMENTARY MATERIAL}

The Supplementary Material for this article can be found online at: http://journal.frontiersin.org/article/10.3389/fpls.2016.01014

Colombo, S. J., and Timmer, V. R. (1992). Limits of tolerance to high temperatures causing direct and indirect damage to white spruce. Tree Physiol. 11, 95-104. doi: 10.1093/treephys/11.1.95

Cregg, B. M. (1994). Carbon allocation, gas exchange, and needle morphology of Pinus ponderosa genotypes known to differ in growth and survival under imposed drought. Tree Physiol. 14, 883-898. doi: 10.1093/treephys/14.7-8-9.883

Cregg, B. M., and Zhang, J. W. (2001). Physiology and morphology of Pinus sylvestris seedlings from diverse sources under cyclic drought stress. For. Ecol. Manage 154, 131-139. doi: 10.1016/S0378-1127(00)00626-5

DeLucia, E. H., Maherali, H., and Carey, E. V. (2000). Climate-driven changes in biomass allocation in pines. Glob. Chang. Biol. 6, 587-593. doi: 10.1046/j.13652486.2000.00338.x

Eilmann, B., Zweifel, R., Buchmann, N., Fonti, P., and Rigling, A. (2009). Droughtinduced adaptation of the xylem in Scots pine and pubescent oak. Tree Physiol. 29, 1011-1020. doi: 10.1093/treephys/tpp035

Ellenberg, H. (1988). Vegetation Ecology of Central Europe. Cambridge: Cambridge University Press.

Fox, J., and Weisberg, S. (2011). An R Companion to Applied Regression. Thousand Oaks, CA: Sage Publication.

Galiano, L., Martínez-Vilalta, J., and Lloret, F. (2011). Carbon reserves and canopy defoliation determine the recovery of Scots pine $4 \mathrm{yr}$ after a drought episode. New Phytol. 190, 750-759. doi: 10.1111/j.1469-8137.2010.03628.x

Günthardt-Goerg, M. S., Kuster, T. M., Arend, M., and Vollenweider, P. (2013). Foliage response of young central European oaks to air warming, drought and soil type. Plant Biol. 15, 185-197. doi: 10.1111/j.1438-8677.2012.00665.x

Hampe, A., and Petit, R. J. (2005). Conserving biodiversity under climate change: the rear edge matters. Ecol. Lett. 8, 461-467. doi: 10.1111/j.14610248.2005.00739.x

Hanson, P. J., Todd, D. E., and Amthor, J. S. (2001). A six-year study of sapling and large-tree growth and mortality responses to natural and induced variability in precipitation and throughfall. Tree Physiol. 21, 345-358. doi: 10.1093/treephys/21.6.345

Hijmans, R. J., Cameron, S. E., Parra, J. L., Jones, P. G., and Jarvis, A. (2005). Very high resolution interpolated climate surfaces for global land areas. Int. J. Climatol. 25, 1965-1978. doi: 10.1002/joc.1276

Hothorn, T., Bretz, F., and Westfall, P. (2008). Simultaneous inference in general parametric models. Biom. J. 50, 346-363. doi: 10.1002/bimj.200810425

Hsiao, T. C., and Acevedo, E. (1974). Plant responses to water deficit, water use efficency, and drought resistance. Agric. Meteorol. 14, 59-84. doi: 10.1016/00021571(74)90011-9

Irvine, J., Perks, M. P., Magnani, F., and Grace, J. (1998). The response of Pinus sylvestris to drought: stomatal control of transpiration and hydraulic conductance. Tree Physiol. 18, 393-402. doi: 10.1093/treephys/18. 6.393

Jagodziński, A. M., and Kałucka, I. (2008). Age-related changes in leaf area index of young Scots pine stands. Dendrobiology 59, 57-65. 
Kirtman, B., Power, S. B., Adedoyin, J. A., Boer, G. J., Bojariu, R., Camilloni, I., et al. (2013). "Near-term climate change: projections and predictability," in Climate Change 2013: The Physical Science Basis. Contribution of Working Group I to the Fifth Assessment Report of the Intergovernmental Panel on Climate Change, eds T. F. Stocker, D. Qin, G.-K. Plattner, M. Tignor, S. K. Allen, J. Boschung, et al. (Cambridge: Cambridge University Press), 953-1028.

Klein, T., Di Matteo, G., Rotenberg, E., Cohen, S., and Yakir, D. (2013). Differential ecophysiological response of a major Mediterranean pine species across a climatic gradient. Tree Physiol. 33, 26-36. doi: 10.1093/treephys/tps116

Knutzen, F., Meier, I. C., and Leuschner, C. (2015). Does reduced precipitation trigger physiological and morphological drought adaptations in European beech (Fagus sylvatica L.)? Comparing provenances across a precipitation gradient. Tree Physiol. 35, 949-963. doi: 10.1093/treephys/tpv057

Kozlowski, T. T., and Pallardy, S. G. (2002). Acclimation and adaptive responses of woody plants to environmental stresses. Bot. Rev. 68, 270-334. doi: 10.1663/0006-8101(2002)068[0270:AAAROW]2.0.CO;2

Kubiske, M. E., and Abrams, M. D. (1992). Photosynthesis, water relations, and leaf morphology of xeric versus mesic Quercus rubra ecotypes in central Pennsylvania in relation to moisture stress. Can. J. For. Res. 22, 1402-1407. doi: 10.1139/x92-186

Lambers, H., Chapin, F. S. III, and Pons, T. L. (2008). Plant Physiological Ecology, 2nd Edn. New York, NY: Springer.

Lee, T. D., Reich, P. B., and Bolstad, P. V. (2005). Acclimation of leaf respiration to temperature is rapid and related to specific leaf area, soluble sugars and leaf nitrogen across three temperate deciduous tree species. Funct. Ecol. 19, 640-647. doi: 10.1111/j.1365-2435.2005.01023.x

Lloret, F., Peñuelas, J., and Ogaya, R. (2004a). Establishment of co-existing Mediterranean tree species under a varying soil moisture regime. J. Veg. Sci. 15, 237-244. doi: 10.1111/j.1654-1103.2004.tb02258.x

Lloret, F., Siscart, D., and Dalmases, C. (2004b). Canopy recovery after drought dieback in holm-oak Mediterranean forests of Catalonia (NE Spain). Glob. Chang. Biol. 10, 2092-2099. doi: 10.1111/j.1365-2486.2004.00870.x

Mäkelä, A., Hari, P., Berninger, F., Hänninen, H., and Nikinmaa, E. (2004). Acclimation of photosynthetic capacity in Scots pine to the annual cycle of temperature. Tree Physiol. 24, 369-376. doi: 10.1093/treephys/24.4.369

Martínez-Vilalta, J., Cochard, H., Mencuccini, M., Sterck, F., Herrero, A., Korhonen, J. F. J., et al. (2009). Hydraulic adjustment of Scots pine across Europe. New Phytol. 184, 353-364. doi: 10.1111/j.1469-8137.2009.02954.x

Martínez-Vilalta, J., López, B. C., Adell, N., Badiella, L., and Ninyero, M. (2008). Twentieth century increase of Scots pine radial growth in NE Spain shows strong climate interactions. Glob. Chang. Biol. 14, 2868-2881. doi: 10.1111/j.1365-2486.2008.01685.x

McDowell, N. G., and Allen, C. D. (2015). Darcy's law predicts widespread forest mortality under climate warming. Nat. Clim. Chang. 5, 669-672. doi: $10.1038 /$ nclimate 2641

McDowell, N. G., Beerling, D. J., Breshears, D. D., Fisher, R. A., Raffa, K. F., and Stitt, M. (2011). The interdependence of mechanisms underlying climate-driven vegetation mortality. Trends Ecol. Evol. 26, 523-532. doi: 10.1016/j.tree.2011.06.003

Mencuccini, M., and Grace, J. (1995). Climate influences the leaf area/sapwood area ratio in Scots pine. Tree Physiol. 15, 1-10. doi: 10.1093/treephys/15.1.1

Michelot, A., Bréda, N., Damesin, C., and Dufrêne, E. (2012). Differing growth responses to climatic variations and soil water deficits of Fagus sylvatica, Quercus petraea and Pinus sylvestris in a temperate forest. For. Ecol. Manage. 265, 161-171. doi: 10.1016/j.foreco.2011.10.024

Mitchell, P. J., O’Grady, A. P., Tissue, D. T., White, D. A., Ottenschlaeger, M. L., and Pinkard, E. A. (2013). Drought response strategies define the relative contributions of hydraulic dysfunction and carbohydrate depletion during tree mortality. New Phytol. 197, 862-872. doi: 10.1111/nph.12064

Modrzyński, J., and Eriksson, G. (2002). Response of Picea abies populations from elevational transects in the Polish Sudety and Carpathian mountains to simulated drought stress. For. Ecol. Manag. 165, 105-116. doi: 10.1016/S03781127(01)00651-X

Monson, R. K., and Grant, M. C. (1989). Experimental studies of ponderosa Pine. III. Differences in photosynthesis, stomatal conductance, and water-use efficiency between two genetic lines. Am. J. Bot. 76:1041. doi: 10.2307/2444526

Niinemets, Ü. (2010). Responses of forest trees to single and multiple environmental stresses from seedlings to mature plants: past stress history, stress interactions, tolerance and acclimation. For. Ecol. Manage. 260, 16231639. doi: 10.1016/j.foreco.2010.07.054

Ogasa, M., Miki, N. H., Murakami, Y., and Yoshikawa, K. (2013). Recovery performance in xylem hydraulic conductivity is correlated with cavitation resistance for temperate deciduous tree species. Tree Physiol. 33, 335-344. doi: 10.1093/treephys/tpt010

Oleksyn, J., Reich, P. B., Chalupka, W., and Tjoelker, M. G. (1999). Differential above- and below-ground biomass accumulation of European Pinus sylvestris populations in a 12-year-old provenance experiment. Scand. J. For. Res. 14, 7-17. doi: 10.1080/02827589908540804

Oleksyn, J., Reich, P. B., Rachwal, L., Tjoelker, M. G., and Karolewski, P. (2000). Variation in aboveground net primary production of diverse European Pinus sylvestris populations. Trees 14, 415-421. doi: 10.1007/PL00009775

Oleksyn, J., Tjoelker, M., and Reich, P. (1998). Adaptation to changing environment in Scots pine populations across a latitudinal gradient. Silva Fenn. 32, 129-140. doi: 10.14214/sf.691

Oleksyn, J., Tjoelker, M. G., and Reich, P. B. (1992). Growth and biomass partitioning of populations of European Pinus sylvestris L. under simulated 50 and $60 \mathrm{~N}$ daylengths: evidence for photoperiodic ecotypes. New Phytol. 120, 561-574. doi: 10.1111/j.1469-8137.1992.tb01806.x

Peña-Rojas, K., Aranda, X., Joffre, R., and Fleck, I. (2005). Leaf morphology, photochemistry and water status changes in resprouting Quercus ilex during drought. Funct. Plant Biol. 32, 117. doi: 10.1071/FP04137

Peñuelas, J., Sardans, J., Estiarte, M., Ogaya, R., Carnicer, J., Coll, M., et al. (2013). Evidence of current impact of climate change on life: a walk from genes to the biosphere. Glob. Chang. Biol. 19, 2303-2338. doi: 10.1111/gcb.12143

Poorter, H., Niklas, K. J., Reich, P. B., Oleksyn, J., Poot, P., and Mommer, L. (2012). Biomass allocation to leaves, stems and roots: meta-analyses of interspecific variation and environmental control. New Phytol. 193, 30-50. doi: 10.1111/j.1469-8137.2011.03952.x

R Core Team (2015). R: A Language and Environment for Statistical Computing. Vienna: R Foundation Statistical Computing.

Reich, P. B., and Oleksyn, J. (2008). Climate warming will reduce growth and survival of Scots pine except in the far north. Ecol. Lett. 11, 588-597. doi: 10.1111/j.1461-0248.2008.01172.x

Rennenberg, H., Loreto, F., Polle, A., Brilli, F., Fares, S., Beniwal, R. S., et al. (2006). Physiological responses of forest trees to heat and drought. Plant Biol. 8, 556-571. doi: 10.1055/s-2006-924084

Richards, L. A. (1941). A pressure-membrane extraction apparatus for soil solution'. Soil Sci. 51, 377-386. doi: 10.1097/00010694-194105000-00005

Richter, S., Kipfer, T., Wohlgemuth, T., Calderón Guerrero, C., Ghazoul, J., and Moser, B. (2012). Phenotypic plasticity facilitates resistance to climate change in a highly variable environment. Oecologia 169, 269-279. doi: 10.1007/s00442011-2191-x

Rose, L., Leuschner, C., Köckemann, B., and Buschmann, H. (2009). Are marginal beech (Fagus sylvatica L.) provenances a source for drought tolerant ecotypes? Eur. J. For. Res. 128, 335-343. doi: 10.1007/s10342-009-0268-4

Ryan, M. G., Phillips, N., and Bond, B. J. (2006). The hydraulic limitation hypothesis revisited. Plant Cell Environ. 29, 367-381. doi: 10.1111/j.13653040.2005.01478.x

Sala, A., Piper, F., and Hoch, G. (2010). Physiological mechanisms of droughtinduced tree mortality are far from being resolved. New Phytol. 186, 274-281. doi: 10.1111/j.1469-8137.2009.03167.x

Salmon, Y., Torres-Ruiz, J. M., Poyatos, R., Martinez-Vilalta, J., Meir, P., Cochard, H., et al. (2015). Balancing the risks of hydraulic failure and carbon starvation: a twig scale analysis in declining Scots pine. Plant Cell Environ. 38, 2575-2588. doi: 10.1111/pce.12572

Seiler, J. R., and Johnson, J. D. (1988). Physiological and morphological responses of three half-sib families of loblolly pine to water-stress conditioning. For. Sci. 34, 487-495.

Sterck, F. J., Martínez-Vilalta, J., Mencuccini, M., Cochard, H., Gerrits, P., Zweifel, R., et al. (2012). Understanding trait interactions and their impacts on growth in Scots pine branches across Europe. Funct. Ecol. 26, 541-549. doi: 10.1111/j.1365-2435.2012.01963.x

Sterck, F. J., Zweifel, R., Sass-Klaassen, U., and Chowdhury, Q. (2008). Persisting soil drought reduces leaf specific conductivity in Scots pine (Pinus sylvestris) and pubescent oak (Quercus pubescens). Tree Physiol. 28, 529-536. doi: $10.1093 /$ treephys/28.4.529 
Taeger, S., Fussi, B., Konnert, M., and Menzel, A. (2013a). Large-scale genetic structure and drought-induced effects on European Scots pine (Pinus sylvestris L.) seedlings. Eur. J. For. Res. 132, 481-496. doi: 10.1007/s10342-013-0689-y

Taeger, S., Sparks, T. H., and Menzel, A. (2015). Effects of temperature and drought manipulations on seedlings of Scots pine provenances. Plant Biol. 17, 361-372. doi: $10.1111 /$ plb.12245

Taeger, S., Zang, C., Liesebach, M., Schneck, V., and Menzel, A. (2013b). Impact of climate and drought events on the growth of Scots pine (Pinus sylvestris L.) provenances. For. Ecol. Manage. 307, 30-42. doi: 10.1016/j.foreco.2013.06.053

Therneau, T. M., and Grambsch, P. M. (2000). Modeling Survival Data: Extending the Cox Model. New York, NY: Springer.

Thiel, D., Kreyling, J., Backhaus, S., Beierkuhnlein, C., Buhk, C., Egen, K., et al. (2014). Different reactions of central and marginal provenances of Fagus sylvatica to experimental drought. Eur. J. For. Res. 133, 247-260. doi: 10.1007/s10342-013-0750-x

Thiel, D., Nagy, L., Beierkuhnlein, C., Huber, G., Jentsch, A., Konnert, M., et al. (2012). Uniform drought and warming responses in Pinus nigra provenances despite specific overall performances. For. Ecol. Manage. 270, 200-208. doi: 10.1016/j.foreco.2012.01.034

Tognetti, R., Michelozzi, M., and Giovannelli, A. (1997). Geographical variation in water relations, hydraulic architecture and terpene composition of Aleppo pine seedlings from Italian provenances. Tree Physiol. 17, 241-250. doi: 10.1093/treephys/17.4.241

Valladares, F., Gianoli, E., and Gómez, J. M. (2007). Ecological limits to plant phenotypic plasticity. New Phytol. 176, 749-763. doi: 10.1111/j.14698137.2007.02275.x

Valladares, F., and Sánchez-Gómez, D. (2006). Ecophysiological traits associated with drought in mediterranean tree seedlings: individual responses versus interspecific trends in eleven species. Plant Biol. 8, 688-697. doi: 10.1055/s 2006-924107

Verbeeck, H., Steppe, K., Nadezhdina, N., de Beeck, M. O., Deckmyn, G., Meiresonne, L., et al. (2007). Stored water use and transpiration in Scots pine: a modeling analysis with ANAFORE. Tree Physiol. 27, 1671-1685. doi: 10.1093/treephys/27.12.1671

Wellstein, C., and Cianfaglione, K. (2014). Impact of extreme drought and warming on survival and growth characteristics of different provenences of juvenile Quercus pubescens Willd. Folia Geobot. 49, 31-47. doi: 10.1007/s12224-0139186-9

Xiao, C.-W., and Ceulemans, R. (2004). Allometric relationships for needle area of different needle age classes in young Scots pines: needles, branches and trees. Forestry 77, 369-382. doi: 10.1093/forestry/77.5.369

Zhang, Y.-J., Meinzer, F. C., Hao, G.-Y., Scholz, F. G., Bucci, S. J., Takahashi, F. S. C., et al. (2009). Size-dependent mortality in a Neotropical savanna tree: the role of height-related adjustments in hydraulic architecture and carbon allocation. Plant Cell Environ. 32, 1456-1466. doi: 10.1111/j.1365-3040.2009.02012.x

Conflict of Interest Statement: The authors declare that the research was conducted in the absence of any commercial or financial relationships that could be construed as a potential conflict of interest.

Copyright (c) 2016 Seidel and Menzel. This is an open-access article distributed under the terms of the Creative Commons Attribution License (CC BY). The use, distribution or reproduction in other forums is permitted, provided the original author(s) or licensor are credited and that the original publication in this journal is cited, in accordance with accepted academic practice. No use, distribution or reproduction is permitted which does not comply with these terms. 